\title{
Product Market Competition and R\&D Investment: Evidence From Textual Analysis on Annual Report of China's Listed Firms
}

\author{
Ziyu Song ${ }^{1}$ (1) ${ }^{\text {a }}$, Shuming Ren ${ }^{1}$ \\ 1 School of Economics and Management, Dalian University of Technology, China \\ Keywords: product market competition, r\&d investment, textual analysis
}

\section{Asian Economics Letters}

We investigate the relationship between product market competition (measured by textual analysis of annual reports) and Research and Development (R\&D) investment of China's listed firms. Empirical results show that competition promotes innovation. Economic policy uncertainty negatively regulates the relationship. In addition, this relationship is affected by the regional heterogeneity of firms.

\section{Introduction}

China's extensive growth relies on productivity, which suffered following the 2008 global financial crisis. China has formulated a series of innovation-driven development policies to revive its economy. One of the most important policies aims to promote market integration and encourage product market competition. Research and Development (R\&D) investment is the foundation of firm innovation. Therefore, the impact of a market competitive environment on a firm's R\&D investment needs to be understood.

The traditional measures of product market competition are mainly derived from the accounting perspective, such as the Concentration Ratio (CR) and the HerfindahlHirschman Index (HHI). The text analysis method based on the annual report of listed firms has obvious advantages over the traditional accounting methods in measuring product market competition. First, the annual report must meet the regulatory standards. Thus, the annual report contains direct information about a firm's products. Second, the annual report is updated annually. In contrast, the Securities Regulatory Commission Industry Classification codes for product location are static, and the firm's industry codes rarely change over time. Moreover, a text-based approach can compare the level of competition among firms across industries, which is a limitation of the measures from the accounting perspective.

The relationship between product market competition and $\mathrm{R} \& \mathrm{D}$ investment has a rich history in economics. A large number of studies has studied it, but there is still no consensus. Schumpeter (1942) argued that product market competition exhibits a negative effect on innovation. Because of more stable and more internal funds to invest in innovation, large firms innovate more and can further protect their innovations. By contrast, Arrow (1962) noted that competition is good for innovation. On the one hand, monopolistic firms have less incentives to innovate than competitive firms. On the other hand, competitive firms make profits from their innovations. Aghion et al. (2002) documented an inverted-U shape relationship between competition and firm innovation for the UK. Furthermore, they found that competition positively affects innovation to a certain level of competition but negatively affects innovation after such a level is reached. Two serious problems that weaken the robustness and validity of the results are: (1) measures of competition are mainly derived from the accounting perspective, and these measures investigate competition at the industry-level rather than the firm-level; and (2) the dynamics and endogeneity of product market competition and R\&D investment are often ignored.

This study contributes to our understanding of the relationship between product market competition and R\&D investment along three lines. First, we collect annual reports of listed firms and utilize the crawl technology to obtain the frequency of "competition" in the annual reports. Second, as far as we know, this study is the first to focus on the dynamic and endogeneity aspects of the relationship between product market competition and R\&D investment, which are often neglected. To address these issues, we employ the system generalized method of moments (GMM, Wintoki et al., 2012) estimator to omit the endogeneity concern and obtain more accurate results. Finally, we examine the negative regulatory effect of economic policy uncertainty $(E P U)$ on the relationship between competition and $\mathrm{R} \& \mathrm{D}$ investment.

\section{Data, models and methodologies}

\section{Data}

Data from China's A-share listed firms (excluding special treatment firms and financial industry firms) are used. The sample period covers 2007-2017. The main variables of the 1701 firms are manually obtained from annual reports. The patent data are derived from the Chinese Research Data Services (CRDS), the EPU index is the one constructed by Baker et al. (2016), and the other data are derived from the China Stock Market and Accounting Research database (CSMAR).

Similar to Li et al. (2013), product market competition (Comp) is measured by the text analysis method. We count the number of occurrences of "competition" and remove 
Table 1: Selected descriptive statistics of variables, 2007-2017

\begin{tabular}{lccccc}
\hline Variable & No. of observations & Mean & Standard deviation & Minimum & Maximum \\
\hline RD & 16975 & 10.53 & 8.747 & 0 & 25.03 \\
Comp & 16931 & 17.71 & 12.09 & 0 & 114 \\
EPU & 16975 & 1.925 & 0.962 & 0.822 & 3.648 \\
Region & 16975 & 1.500 & 0.763 & 1 & 3 \\
Staff & 16975 & 0.0632 & 0.752 & -82.57 & 23.37 \\
Roe & 16975 & 0.0632 & 0.752 & -82.57 & 23.37 \\
Lve & 16975 & 0.443 & 0.207 & 0.00752 & 2.861 \\
Separation & 16267 & 5.281 & 8.112 & -0.0003 & 59.45 \\
Age & 16969 & 2.665 & 0.432 & 0 & 3.689 \\
Size & 16975 & 22.10 & 1.310 & 18.68 & 0 \\
Owner & 16975 & 0.483 & 0.500 & 0 & 28.51 \\
HHI & 16945 & 17.6233 & 11.7667 & 0 & 1 \\
\hline
\end{tabular}

This table has descriptive statistics of variables: (1) the main variables are winsorized with a trimming fraction of $1 \%$; (2) Owner $=1$ for state-owned firms and owner=0 for non-stateowned firms; and (3) when a firm is located in the eastern region, region=1, when a firm is located in the central region, region $=2$, and when the firm is located in the western region, region $=3$.

any case where "not," “less," or "limited” from a firm's annual report. The variable $R D$ is the logarithm of one plus annual R\&D investment.

In the extended analysis, we examine the regulatory effect of the EPU on the relationship between product market competition and R\&D investment. Baker et al. (2016) compile a frequency count of articles on policy and economic uncertainty in Hong Kong's main English-language newspaper, the South China Morning Post (SCMP), to measure uncertainty in China's economic policy. The method follows the index of EPU in the USA and other major economies worldwide. In this study, we annualized the index of EPU by the arithmetic mean method.

The firm level control variables used are: region (Region), staff of the firm (Staff), return on equity $(R O E)$, leverage ratio (Lve), two weight separation rate (Separation), firm age (Age), firm size (Size) and firm property (Owner). The HHI is at the industry level. The descriptive statistics of variables are shown in Table 1.

\section{Models and methodology}

We propose the following empirical model:

$$
\begin{aligned}
\text { Comp }_{i t}= & f\left(R D_{i, t-1}, \text { Controls }_{i t}, \eta_{i}\right) \\
R D_{i t}= & \alpha+\beta R D_{i, t-1}+\lambda_{1} \text { Comp }_{i t}+\lambda_{2} \text { Comp }_{i t}^{2} \\
& +\lambda_{3} E P U_{i t}+\lambda_{4} E P U_{i t} * \text { Comp }_{i t} \\
& +X_{1} \text { Controls }_{i t}+\eta_{i}+\varepsilon_{i t}
\end{aligned}
$$

All variables are as defined previously; $\eta_{i}$ represents the individual effect, and $\varepsilon_{i t}$ represents the random error term. $C o m p_{i t}$ and $R D_{i, t-1}$ are both correlated with the random error $\varepsilon_{i t}$. We use the system GMM to alleviate this endogeneity concern. Considering that the macro-economy may have an impact on the relationship between product market competition and enterprise $\mathrm{R} \& \mathrm{D}$ investment, an interaction term $\left(E P U^{*} C o m p\right)$ is added to examine whether EPU has a regulatory effect on the relationship.

\section{Empirical results}

\section{Main results}

In this section, we report the empirical results of the dynamic relationship between product market competition and R\&D investment. Table 2 reports the results obtained from the system GMM estimator. The value of AR (2) and Hansen test in the system GMM model make it impossible to reject the null hypothesis without second-order serial correlation. Therefore, the model is reasonable. The system GMM results reveal that product market competition exhibits a significant positive impact on $R \& D$ investment. The coefficient of Comp ${ }^{2}$ is significantly negative. Therefore, the marginal effect of product market competition on R\&D investment decreases. The relationship between product market competition and R\&D investment shows an inverted-U shape. At the same time, we find that the interaction term of $E P U^{*}$ Comp has a significant and negative effect. The coefficients of EPU*Comp and Comp are opposite, which imply that EPU reduces the incentive effect of product markets competition on $\mathrm{R} \& \mathrm{D}$ investment. In other words, economic uncertainty will negatively regulate the incentive effect of product market competition on firm innovation.

\section{Heterogeneity test}

In this section, we test whether the relationship between product market competition and R\&D investment is different among firms in different regions. Like Ren \& Song (2020), we divided firms in the sample into three subsamples according to their location: eastern, central and western regions. In China, the eastern provincial region is the most developed, with the highest level of marketization, and the most complete intellectual property legal system, followed by the central provincial region. By comparison, the western provincial region is the least developed. The regression results of subsamples are shown in Table 3 . The stimulating effect of product market competition on $R \& D$ investment of firms is most significant in the eastern 
Table 2: The System GMM results

\begin{tabular}{|c|c|c|c|}
\hline \multirow[b]{2}{*}{ Variables } & \multicolumn{3}{|c|}{ System GMM } \\
\hline & $R D$ & $R D$ & $R D$ \\
\hline \multirow[t]{2}{*}{$R D(-1)$} & $0.403^{* * *}$ & $0.398^{* * *}$ & $0.402^{* * *}$ \\
\hline & $(0.025)$ & $(0.025)$ & $(0.045)$ \\
\hline \multirow[t]{2}{*}{ Comp } & $0.092^{* * *}$ & $0.227^{* * *}$ & $0.551^{* * *}$ \\
\hline & $(0.032)$ & $(0.057)$ & $(0.145)$ \\
\hline \multirow[t]{2}{*}{ Comp ${ }^{2}$} & & $-0.003^{* *}$ & $-0.012^{* * *}$ \\
\hline & & $(0.001)$ & $(0.003)$ \\
\hline \multirow[t]{2}{*}{$E P U$} & & & 28.891 \\
\hline & & & $(50.251)$ \\
\hline \multirow[t]{2}{*}{ Comp ${ }^{*} E P U$} & & & $-0.045^{* * *}$ \\
\hline & & & $(0.012)$ \\
\hline \multirow[t]{2}{*}{ Size } & $2.175^{* *}$ & $2.375^{* *}$ & -1.761 \\
\hline & $(0.960)$ & $(1.046)$ & (2.423) \\
\hline \multirow[t]{2}{*}{ Lev } & -1.571 & -1.362 & -4.020 \\
\hline & $(2.064)$ & (2.233) & (3.339) \\
\hline \multirow[t]{2}{*}{$R O E$} & -0.786 & -0.707 & -0.371 \\
\hline & $(0.920)$ & $(0.856)$ & $(0.576)$ \\
\hline \multirow[t]{2}{*}{ Owner } & -2.097 & -1.953 & -0.568 \\
\hline & (2.130) & (2.277) & (17.619) \\
\hline \multirow[t]{2}{*}{ Age } & $-1.530^{*}$ & -1.020 & $-12.495^{* *}$ \\
\hline & $(0.907)$ & $(0.953)$ & $(6.275)$ \\
\hline \multirow[t]{2}{*}{ Separation } & 0.008 & 0.013 & 0.171 \\
\hline & $(0.054)$ & $(0.052)$ & $(0.398)$ \\
\hline \multirow[t]{2}{*}{ Staff } & $-2.166^{* * *}$ & $-2.118^{* * *}$ & $5.589^{*}$ \\
\hline & $(0.484)$ & $(0.495)$ & $(2.905)$ \\
\hline \multirow[t]{2}{*}{$\mathrm{HHI}$} & -2.481 & -2.304 & $-132.770^{* * *}$ \\
\hline & $(4.647)$ & $(4.552)$ & (45.917) \\
\hline Year & YES & YES & YES \\
\hline Ind & YES & YES & YES \\
\hline Region & YES & YES & YES \\
\hline$A R(1)$ test( $p$ value) & 0 & 0 & 0 \\
\hline$A R(2)$ test( $p$ value) & 0.28 & 0.45 & 0.39 \\
\hline Hansen test( $p$ value) & 0.1 & 0.12 & 0.09 \\
\hline \multirow[t]{2}{*}{ Constant } & 0.000 & -93.944 & 0.000 \\
\hline & $(0.000)$ & $(105.516)$ & $(0.000)$ \\
\hline Observations & 14,531 & 14,531 & 14,531 \\
\hline Number of id & 1,696 & 1,696 & 1,696 \\
\hline
\end{tabular}

This table reports results of the dynamic model. Two points are important: $(1) * * * * * * *$ represent statistical significance at the $1 \%, 5 \%, 10 \%$ levels, respectively; and (2) robust standard errors are in parentheses.

provincial region, followed by firms in the central provincial region, while the relationship is insignificant for the western provincial region. The different results of subsamples may be attributed to two factors. First, under the existing industrial policies, firms in the western region are more likely to receive government subsidies, market access restrictions, and other "conveniences" than firms in other regions. Thus, the stimulating effect of product market competition on R\&D investment is suppressed. Second, firms in the western region have relatively weak competitive con- sciousness and imperfect innovation protection mechanism, thereby weakening the stimulating effect of product market competition on R\&D investment.

\section{Conclusion}

Through a detailed quantitative research that mitigates the effects of endogeneity, this study attempts to present a novel perspective to explain the relationship between market structure and firm innovation in China. The results 
Table 3: System GMM results for eastern, central and western regions

\begin{tabular}{|c|c|c|c|}
\hline & Eastern & Central & Western \\
\hline Variables & $R D$ & $R D$ & $R D$ \\
\hline \multirow[t]{2}{*}{$R D(-1)$} & $0.390^{* * *}$ & $0.394^{* * *}$ & $0.515^{* * *}$ \\
\hline & $(0.032)$ & $(0.045)$ & (0.049) \\
\hline \multirow[t]{2}{*}{ Comp } & $0.231^{* * *}$ & $0.148^{* *}$ & -0.007 \\
\hline & $(0.061)$ & $(0.075)$ & (0.109) \\
\hline \multirow[t]{2}{*}{ Comp ${ }^{2}$} & $-0.003^{* *}$ & $-0.002^{*}$ & 0.001 \\
\hline & (0.001) & $(0.001)$ & $(0.002)$ \\
\hline \multirow[t]{2}{*}{ Size } & 1.621 & 0.933 & $2.104^{* *}$ \\
\hline & (1.008) & $(0.713)$ & (1.016) \\
\hline \multirow[t]{2}{*}{ Lev } & -1.271 & -0.864 & -4.054 \\
\hline & (2.061) & $(2.033)$ & (2.784) \\
\hline \multirow[t]{2}{*}{$R O E$} & -0.459 & -2.612 & -0.797 \\
\hline & (0.474) & (2.189) & $(0.602)$ \\
\hline \multirow[t]{2}{*}{ Owner } & 0.267 & -1.135 & -1.075 \\
\hline & (1.772) & (1.399) & (2.735) \\
\hline \multirow[t]{2}{*}{ Age } & $-1.752^{*}$ & -0.570 & 0.619 \\
\hline & (1.053) & $(1.357)$ & (1.750) \\
\hline \multirow[t]{2}{*}{ Separation } & 0.004 & -0.013 & 0.003 \\
\hline & $(0.052)$ & $(0.074)$ & (0.055) \\
\hline \multirow[t]{2}{*}{ Staff } & $-1.556^{* * *}$ & -0.516 & -1.258 \\
\hline & $(0.512)$ & $(0.617)$ & $(0.926)$ \\
\hline \multirow[t]{2}{*}{$\mathrm{HHI}$} & 0.668 & -7.740 & 4.775 \\
\hline & (6.148) & (9.754) & (6.336) \\
\hline Year & Yes & Yes & Yes \\
\hline Ind & Yes & Yes & Yes \\
\hline \multirow[t]{2}{*}{ Constant } & -48.499 & -11.767 & $-37.230^{*}$ \\
\hline & $(86.563)$ & $(12.516)$ & (20.644) \\
\hline Observations & 9,677 & 2,443 & 2,411 \\
\hline Number of id & 1,147 & 278 & 271 \\
\hline
\end{tabular}

This table shows the regression results of firms in different regions-namely, eastern, central and western provinces. Two points are important: (1) ******** represent statistical significance at the $1 \%, 5 \%, 10 \%$ levels, respectively; and (2) robust standard errors are in parentheses.

show that firm's management increases R\&D investment in the current period when the product market competition is considerably intense. The relationship between product market competition and R\&D investment is an inverted$\mathrm{U}$ shape, which represents the diminishing marginal effect. $E P U$ weakens the incentive effect of product market competition on firm $R \& D$ investment. The incentive effect of product market competition on $\mathrm{R} \& \mathrm{D}$ investment is most significant in the eastern region, but it disappears in the western region. Therefore, the government should shift from traditional industrial policies to competitive and innovative policies, formulate industrial policies (such as property rights system, antimonopoly, and anticorruption), improve market mechanism, and promote fair competition among firms.

Submitted: August 26, 2020 AEDT, Accepted: October 04, 2020 AEDT 


\section{REFERENCES}

Aghion, P., Bloom, N., Blundell, R., Griffith, R., \& Howitt, P. (2002). Competition and Innovation: An Inverted-U Relationship[J]. The Quarterly Journal of Economics. https://doi.org/10.3386/w9269

Arrow, K. J. (1962). Economic welfare and the allocation of resources for innovation. In The Rate and Direction of Inventive Activity (pp. 609-626). Princeton University Press. https://doi.org/10.1515/97 81400879762-024

Baker, S. R., Bloom, N., \& Davis, S. J. (2016). Measuring Economic Policy Uncertainty. Quarterly Journal of Economics, 131(4), 1593-1636. https://do i.org/10.1093/aje/qjw024

Li, F., Lundholm, R. J., \& Minnis, M. (2013). A measure of competition based on 10-k filings. Journal of Accounting Research, 51(2), 399-436. https://doi.o rg/10.1111/j.1475-679x.2012.00472.x
Ren, S., \& Song, Z. (2020). Intellectual capital and firm innovation: Incentive effect and selection effect[J]. Applied Economics Letters, 1-7. https://do i.org/10.1080/13504851.2020.1767281

Schumpeter, J. A. (1942). Capitalism, Socialism, and Democracy[J]. American Economic Review, 3(4), 594-602.

Wintoki, M. B., Linck, J. S., \& Netter, J. M. (2012). Endogeneity and the dynamics of internal corporate governance. Journal of Financial Economics, 105(3), 581-606. https://doi.org/10.1016/i.jfineco.2012.03.00 $\underline{5}$ 